\title{
The Effect of Geraniol on Liver Regeneration After Hepatectomy in Rats
}

\author{
MEDIHA CANBEK ${ }^{1}$, MUSTAFA UYANOGLU ${ }^{1}$, SELCUK CANBEK ${ }^{2}$, EMRE CEYHAN ${ }^{1}$, \\ AHMET OZEN $^{1}$, BASAK DURMUS ${ }^{1}$ and OZGE TURGAK ${ }^{1}$ \\ ${ }^{1}$ Department of Biology, Faculty of Science, and ${ }^{2}$ Department of Computer Engineering, \\ Faculty of Engineering and Architecture, Eskisehir Osmangazi University, Eskisehir, Turkey
}

\begin{abstract}
Geraniol is a monoterpenoid alcohol that has a hepatoprotective effect. We investigated the regenerative effects of geraniol in rats after a $70 \%$ partial hepatectomy (PH). Using Wistar albino rats, nine groups were created: Group I was the control group, while the remaining groups received a single intraperitoneal dose of saline, Silymarin, or geraniol after PH. A $70 \%$ PH was performed on all groups except for groups II and III. Blood serum samples were obtained for alanine amino transferase (ALT) analysis. Then liver tissues were harvested for histological and realtime polymerase chain reaction (PCR) analyses. Tumor necrosis factor- $\alpha(T N F \alpha)$ and interleukin 6 (IL6) gene expression were examined 24 and 48 h after PH. ALT levels were found to be statistically significantly increased in all PH-treated groups. TNF $\alpha$ and IL6 gene expression levels were elevated in geraniol-treated groups. Histological evaluation revealed a hepatoprotective effect for geranioltreated groups. Our results suggest that geraniol plays a significant role during liver regeneration, which involves the elevated expression of TNF $\alpha$ and IL6 $48 \mathrm{~h}$ after PH.
\end{abstract}

Liver damage or a partial hepatectomy $(\mathrm{PH})$ of the liver increases mitotic activity in the liver. Such regeneration continues until the hepatic lobes reach mature dimensions. Studies of rat liver show that in approximately $70 \%$ of cases, mitosis begins 24-30 h after hepatectomy (1-4).

Hepatic regeneration occurs through enzymatic and humoral mechanisms that involve hormones, growth factors, cytokines, activators, and inhibitors $(5,6)$. In the first few

This article is freely accessible online.

Correspondence to: Mediha Canbek, Department of Biology, Faculty of Science, Eskisehir Osmangazi University, 26480 Eskisehir, Turkey. Tel: +902222393750 ext. 2849, Fax: +90 2222393578,e-mail: mcanbek@ogu.edu.tr

Key Words: ALT, IL6, monoterpenoid alcohol, RT-PCR, TNF $\alpha$. hours following hepatectomy, many genes related to the cytokine network are induced, and mRNA levels increase for tumor necrosis factor- $\alpha$ (TNF $\alpha$ ) and interleukin-6 (IL6) $(7,8)$.

Many factors influence hepatic regeneration, including age, portal circulation, vitamins and infection, among others. In addition, various studies have identified chemical substances (anti-oxidants, etc.) that have positive effects on hepatic regeneration $(9,10)$.

Geraniol, a monoterpenoid alcohol, is an oily, pale yellow liquid (11-13) found among the volatile oils of plants such as roses, geraniums, carnations, and lavender $(12,13)$. Geraniol is an effective anti-oxidant, and a study has demonstrated the protective effects of geraniol on liver (14). However, as far as we are aware there are no studies of geraniol and liver regeneration.

Here, we used a rat model for investigating the effects of geraniol on $T N F \alpha$ and IL6 gene expression 24 and $48 \mathrm{~h}$ after PH.

\section{Materials and Methods}

The experimental protocols for this study were approved by the Institutional Ethical Committee for Animal Care and Use at Eskisehir Osmangazi University, Eskisehir, Turkey. Animals were obtained from the medical and surgical experimental research center at our institute, and all experiments were carried out at this same center (protocol number: 270/2012).

Animals. Male Wistar albino rats with a body weight of 200-250 g were obtained from the Ministry of Health, Refik Saydam National Public Health Agency, and Experimental Animals Production Laboratory, Turkey. The experiment was performed following a period of adaption to the laboratory. The animals were housed in polycarbonate cages in an air-conditioned room with a 12/12-h light/dark cycle, temperature of $22 \pm 2{ }^{\circ} \mathrm{C}$, and $50 \pm 5 \%$ humidity. Throughout the experimental period, the animals were provided with pellet chow and water ad libitum.

Experimental design. Animals were divided into the following nine groups, each consisting of 10 animals: Group I: control group, sacrificed at $0 \mathrm{~h}$; groups II and III: sham-operated control groups sacrificed at 24 and $48 \mathrm{~h}$, respectively; groups IV and V: PH saline- 
treated groups sacrificed at 24 and $48 \mathrm{~h}$, respectively; groups VI and VII: PH Silymarin-treated groups, which were positive control group sacrificed at 24 and $48 \mathrm{~h}$, respectively; groups VIII and IX: $\mathrm{PH}$ geraniol-treated groups sacrificed at 24 and $48 \mathrm{~h}$, respectively.

Chemicals. We used 99\% pure geraniol (Acros Organics Thermo Fisher Scientific Geel, Belgium). Silymarin (Sigma-Aldrich Chemie, Taufkirchen Germany), which has protective and reparative effects on liver, was used as a positive control for regeneration. Geraniol and Silymarin were dissolved in saline solution, and a single intraperitoneal $100 \mathrm{mg} / \mathrm{kg}$ dose was given to the experimental animals $(16,17)$.

Surgical procedure. All surgical procedures were performed under anesthesia with $10 \mathrm{mg} / \mathrm{kg}$ xylazine and $70 \mathrm{mg} / \mathrm{kg}$ ketamine, injected intramuscularly. PH was performed using the Higgins and Anderson technique (18). All rats were housed with a 12-h light/dark schedule and allowed access to food and water ad libitum. In the rat $70 \% \mathrm{PH}$ model, the median and left lobes were resected from male rats. The remaining liver lobes were obtained from defined time points after PH for biochemical, histological and molecular analysis.

Real-time polymerase chain reaction (PCR) assay. RNA isolation from liver tissue was performed using PureLink RNA Mini Kit and Trizol (Applied Biosystems, Paisley, UK), according to the kit protocol. cDNA was reverse transcribed from RNA using the HighCapacity cDNA Kit (Applied Biosystems). For this experiment, we prepared the $2 \mathrm{X}$ RT master mixes using the kit components before preparing the reaction plate. The RT master mix was prepared on ice, adding $2 \mu \mathrm{l}$ of 10X RT buffer, $0.8 \mu \mathrm{l}$ of $25 \mathrm{X}$ dNTP mix (100 $\mathrm{mM}), 2 \mu \mathrm{l}$ of $10 \mathrm{X}$ RT random primers, $1 \mu \mathrm{l}$ of MultiScribe ${ }^{\mathrm{TM}}$ Reverse Transcriptase, $1 \mu \mathrm{l}$ of RNase Inhibitor, $3.2 \mu \mathrm{l}$ of nucleasefree water, and $10 \mu \mathrm{l}$ of RNA sample. cDNA PCR was performed at $25^{\circ} \mathrm{C}$ for $10 \mathrm{~min}, 37^{\circ} \mathrm{C}$ for $120 \mathrm{~min}$, and $85^{\circ} \mathrm{C}$ for $5 \mathrm{~min}$.

The TaqMan Gene Expression Master Mix (Applied Biosystems) was used for the RT-PCR procedure. The RT-PCR reaction mix was prepared using $10 \mu \mathrm{l}$ of $2 \mathrm{X}$ TaqMan Gene Expression Master Mix, $1 \mu \mathrm{l}$ of $20 \mathrm{X}$ TaqMan Gene Expression Assay, and $8 \mu \mathrm{l}$ cDNA template and water. RT-PCR was performed at $50^{\circ} \mathrm{C}$ for $2 \mathrm{~min}, 95^{\circ} \mathrm{C}$ for $10 \mathrm{~min}, 95^{\circ} \mathrm{C}$ for $15 \mathrm{~s}$, and $60^{\circ} \mathrm{C}$ for $1 \mathrm{~min}$. Tumor necrosis factor- $\alpha \quad(T N F \alpha) \quad\left(\mathrm{Rn} 01525859 \_\mathrm{g} 1\right)$ and interleukin-6 (IL6) (Rn01410330_m1) expression is reported relative to that of $\beta$-actin (Rn00667869_m1). RT-PCR gene expression analysis was performed using the Applied Biosystems StepOne Plus RT-PCR protocol.

Determination of serum alanine transaminase (ALT) level. The serum ALT level was analyzed at 24-48 $\mathrm{h}$ to assess liver cell function using a HITACHI-917 auto analyzer and a commercial kit for Human samples (Human Gesellschaft für Biochemica und Diagnostica mbH, Wiesbaden Germany).

Histological evaluation. The liver tissue samples were fixed in $10 \%$ neutral formalin for histological analysis. These tissues were routinely processed and embedded in paraffin. Sections 5-6 $\mu \mathrm{m}$ thick were cut and stained with Harris Hematoxylin and Eosin (H\&E). Tissue samples from all experimental groups were compared.

Statistical analysis. The data were analyzed using analysis of variance (ANOVA) and the Mann-Whitney $U$-test with SPSS version 12.0 for Windows (SPSS, Chicago, IL, USA).

\section{Results and Discussion}

After $48 \mathrm{~h}$, a significant difference $(p<0.001)$ in serum ALT level was found among the treated groups. In the $\mathrm{PH}$ geraniol-treated groups (group VIII and IX), the ALT levels were significantly decreased relative to $\mathrm{PH}$ saline- treated (group IV and V) and PH silymarin-treated groups (group VI and VII). In the PH silymarin-treated groups (24-48 h), that were positive control groups, ALT levels were similarly decreased relative to $\mathrm{PH}$ saline treated groups (group IV and V) $(p<0.05)$ (Figure 1A).

$T N F \alpha$ expression increased within the first $24 \mathrm{~h}$ in the saline, Silymarin, and geraniol-treated PHx groups. The $T N F \alpha$ level in the PH geraniol-treated groups (group VIII and IX) significantly increased in the first $24 \mathrm{~h}$ compared to the control (group I) and sham-operated control (group II and III) groups and $48 \mathrm{~h}$ after $\mathrm{PH}$, the level of expression remained the same. A statistically significant difference $(p<0.05)$ was found at 24 and $48 \mathrm{~h}$ among all groups, except group VII (PH silymarintreated $48 \mathrm{~h}$ ), group VIII (PH geraniol-treated $24 \mathrm{~h}$ ), and group IX (PH geraniol-treated $48 \mathrm{~h}$ ) (Figure 1B).

IL6 levels in the PH geraniol-treated groups (group VIII and IX) at the 48th $\mathrm{h}$ were increased. While a significant difference was not observed in groups VII (PH silymarintreated $48 \mathrm{~h}$ ), VIII (PH geraniol- treated $24 \mathrm{~h}$ ), and IX (PH geraniol- treated $48 \mathrm{~h}$ ), a statistically significant difference was observed among the other groups (Figure 1C).

Histological analysis showed that liver lobule structure was normal in both control (group I) and sham-operated control (group II and III) groups. In contrast, vacuolization, bleeding, and expansion in the sinusoidal spaces were observed in the PH saline- treated groups (group IV and V). (Figure 2B). In the PH geraniol-treated groups (group VIII and IX), these features were reduced at 24 and $48 \mathrm{~h}$ after $\mathrm{PH}$ (Figure 2F). Lastly, mitotic activity and vacuolization were observed in PH silymarin-treated (group VI and VII) (Figure 2D) and $\mathrm{PH}$ geraniol-treated (group VIII and IX) groups (Figure 2F). Both these groups (Figure 2C and E) and $\mathrm{PH}$ saline-treated groups (group IV and V) had tissue integrity (Figure 2A).

Our study investigated the effects of geraniol on regeneration in liver tissue. The results show that geraniol induced a regenerative response after $\mathrm{PH}$. We also found that geraniol triggers $T N F \alpha$ and IL6 expression after PH.

Serum ALT levels were measured to assess liver damage. ALT levels in geraniol and silymarin-treated groups were significantly reduced $48 \mathrm{~h}$ after $\mathrm{PH}$ compared to the $\mathrm{PH}$ saline-treated groups. These results suggest that hepatocytes had functionally recovered from injury. Miura et al. found that in rats that underwent $70 \%$ $\mathrm{PH}, \mathrm{ALT}$ levels peaked in the first $12 \mathrm{~h}$ and had approached the level of ALT found in controls by $48 \mathrm{~h}$ (19). Greif et al. revealed that $48 \mathrm{~h}$ after the application of erythropoietin, ALT levels decreased, also approaching levels observed in a control group 

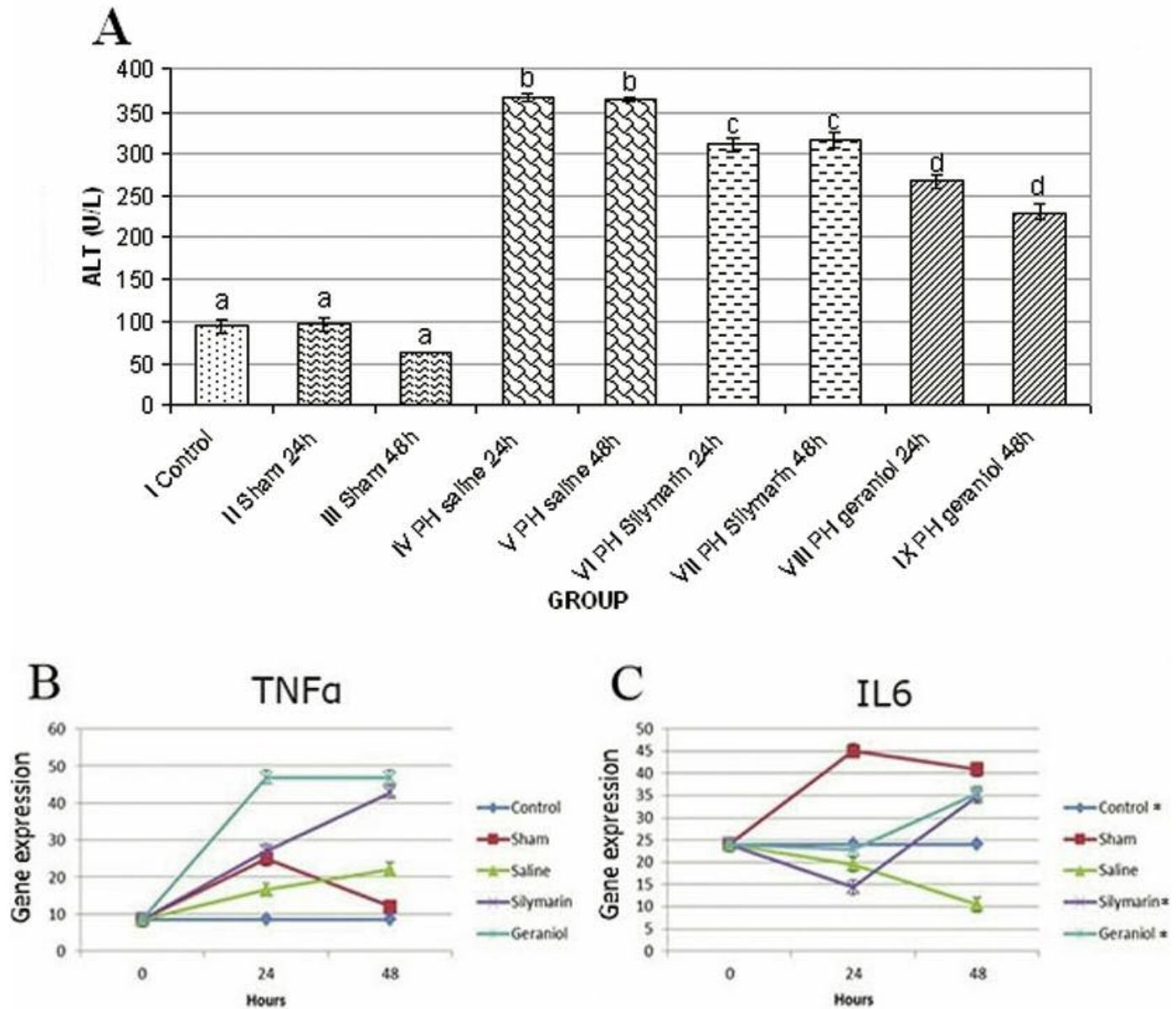

Figure 1. A: Serum alanine transaminase (ALT) in the different treatment groups. Each value is the mean \pm SD of 10 animals per group. Bars with the same letters do not differ significantly. Relative gene expression oftumor necrosis factor- $\alpha(T N F \alpha)(B)$ and interleukin $6(I L 6)(C)$ for all groups. Data are the mean \pm SD. PH: Partial hepatectomy.

(20). Within minutes after liver cell loss, hepatocytes enter the cell cycle. Hepatocyte regeneration occurs in developmental stages. In cell cycle TNF $\alpha$ and IL6, triggers transition from $\mathrm{G}_{0}$ to $\mathrm{G}_{1}(21,22)$.

In our study, mRNA expression of TNF $\alpha$ and IL6 were elevated $24 \mathrm{~h}$ after $\mathrm{PH}$, and by $48 \mathrm{~h}$ the level of gene expression peaked in PH silymarin-treated (group VI and VII) PH geraniol-treated groups (group VIII and IX). In the geraniol-treated groups, TNF $\alpha$ and IL6 expression was similar to those of the $\mathrm{PH}$ silymarin-treated groups. Iwai et al. showed that $24 \mathrm{~h}$ following $67 \% \mathrm{PH}$ in rats, TNFa, and IL6 levels increased, and their levels peaked $48 \mathrm{~h}$ afterwards (8). TNF $\alpha$ and IL6 levels were similar to the control group at $72 \mathrm{~h}$ after PH. Scotte et al. showed that serum IL6 levels peaked within the first $24 \mathrm{~h}$ after $\mathrm{PH}$, then fell and returned to baseline levels (6). Uyanoglu, et al. showed that the serum levels of IL6 $72 \mathrm{~h}$ after PH were similar to levels observed in controls (10). Other studies have shown that the level of
IL6 increased at 2 and $4 \mathrm{~h}$ after PH. Moreover, others report that IL6 expression remains stable up $48 \mathrm{~h}$ after $\mathrm{PH}$, after which it decreases significantly (23-25).

Geraniol applied after PH can increase mitotic activity in hepatocytes, thereby triggering a regenerative process. Studies using PH have found vacuolization, mitotic activity, and remnants of regenerated nuclei $(10,20)$. We observed an increase in mitotic activity in all groups after $\mathrm{PH}$.

\section{Conclusion}

Our study demonstrates the effects of geraniol on liver regeneration in vivo following $\mathrm{PH}$ in rats. We found that geraniol induces regeneration in the liver. However, additional research is necessary to reveal the molecular mechanism of this effect and to fully pharmacologically characterize the activity of geraniol using different doses, exposure times, and delivery methods. 

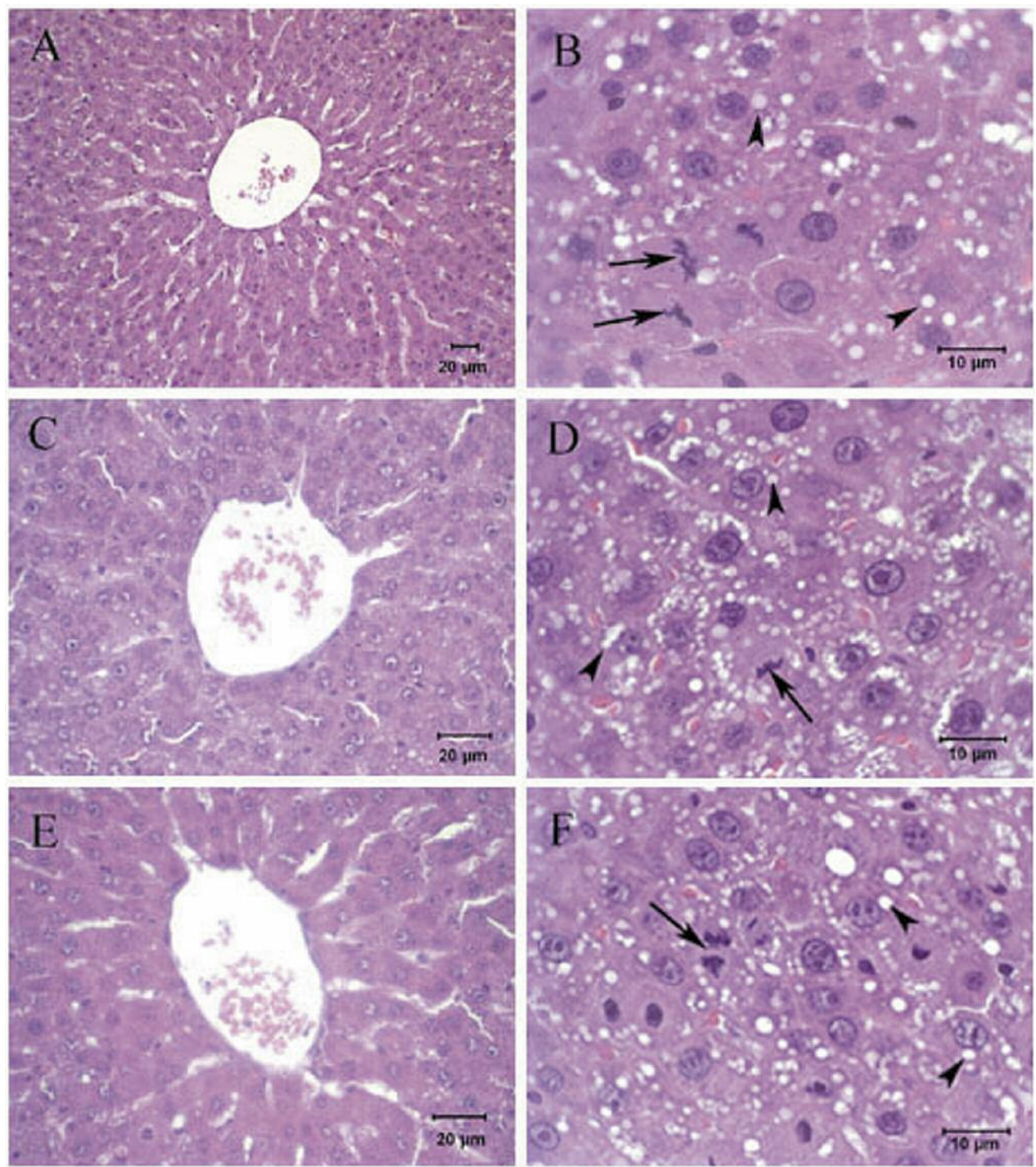

Figure 2. Hepatocytes in sections of liver stained with hematoxylin and eosin. Tissue integrity was preserved in liver sections of partial hepatectomized (PH) saline-treated groups (group IV and V) (A), PH silymarin-treated groups (group VI and VII) (C) and PH geraniol-treated groups (group VIII and IX) (E). Mitotic figures and vacuolization were observed in PH saline-treated groups (group IV and V) (B), PH silymarintreated groups (group VI and VII) (D) and PH geraniol-treated groups (group VIII and IX) (F). Mitotic figures are shown with an arrow, and vacuolization is shown with an arrowhead. 


\section{Acknowledgements}

This study was supported by the Eskisehir Osmangazi University Research Fund, project number 201119025.

\section{References}

1 Ehrenfried JA, Ko TC, Thompson EA and Evers BM: Cell cyclemediated regulation of hepatic regeneration. Surgery 122: 927 935, 1997.

2 Palmes D and Spiegel HU: Animal models of liver regeneration. Biomaterials 25: 1601-1611, 2004.

3 Shimizu T, Togo S, Kumamoto T, Makino H, Morita T, Tanaka K, Kubota T, Ichıkawa Y, Nagasima Y, Okazaki Y, Hayashizaki $\mathrm{Y}$ and Shimada $\mathrm{H}$ : Gene expression during liver regeneration after partial hepatectomy in mice lacking type 1 tumor necrosis factor receptor. J Surg Res 152: 178-188, 2009.

4 Taub R: Liver regeneration: From myth to mechanism. Mol Cell Biol 5: 836-847, 2004.

5 Black D, Lyman S, Heider TR and Behrns KE: Moleclar and cellular features of hepatic regeneration. J Surg Res 117: 306-315, 2004.

6 Scotte M, Masson S, Lyoumi S, Hiron M, Teniere PP, Lebreton JP and Daveau M: Cytokine gene expression in liver following minor or major hepatectomy in rat. Cytokine 9(11): 859-867, 1997.

7 Akerman P, Cote P, Yang SQ, McClain C, Nelson S and Bagby GJ: Antibodies to tumor necrosis factor-alpha inhibit liver regeneration after partial hepatectomy. Am J Physiol 263: G579$585,1992$.

8 Iwai $M$, Cui T-X, Kitamura H, Saito $M$ and Shimazu T: Increased secretion of tumor necrosis factor and interleukin 6 from isolated, perfused liver of rats after partial hepatectomy. Cytokine 13(1): 60-64, 2001.

9 Kapan M, Ipek T, Sad A, Goksel S and Sirin F: Effects of cyclosporin and somatostatin on liver regeneration after partial hepatectomy in rats. Eur Surg Res 28(4): 262-269, 1996.

10 Uyanoglu M, Canbek M, Aral E and Baser K: Effects of carvacrol upon the liver of rats undergoing partial hepatectomy. Phytomedicine 15(3): 226-229, 2008.

11 Banthorpe DV: Biosynthesis of geraniol and nerol and their pd-glucosides in pelargonium graveolens and rosa dilecta biochem. Biochem J 130: 1045-1054, 1972.

12 Chen W and Viljoen AM: Geraniol - a review of a commercially important fragrance material. South African Journal of Botany 76(4): 643-651, 2010.

13 de Cássia da Silveira e Sá R, Andrade LN and de Sousa DP: A review on anti-inflammatory activity of monoterpenes. Molecules 18: 1227-1254, 2013.

14 Cardozo MT, de Conti A, Ong TP, Scolastici C, Purgatto E, Horst MA, Bassoli BK and Moreno FS: Chemopreventive effects of bionone and geraniol during rat hepateocarcinogenesis promotion: Distinct actions on cell proliferation, apoptosis, hmgcoa reductase, and rhoa. J Nutr Biochem 22: 130-135, 2011.
15 Chagas CEA, Vieira A, Ong TP and Moreno FS: Farnesol inhibits cell proliferation and induces apoptosis after partial hepatectomy in rats. Acta Cirúrgica Brasileira 24(5): 377-382, 2009.

16 Lapczynski A, Bhatia SP, Foxenberg RJ, Letizia CS and Api AM: Fragrance material review on geraniol. Food Chem Toxicol 46(11): 160-170, 2008.

17 Mansour HH, Hafez HF and Fahmy NM: Silymarin modulates cisplatin-induced oxidative stress and hepatotoxicity in rats. $\mathbf{J}$ Biochem Mol Biol 39(6): 656-661, 2006.

18 Higgins GM and Anderson RM: Experimental pathology of liver. I. Restoration of liver white rat following partial surgical removal. Arch Pathol 12: 186-202, 1931.

19 Miura Y, Washizawa N, Urita Y, Imai T and Kaneko H: Evaluation of remnant liver function using 13c-breath test in a rat model of $70 \%$ partial hepatectomy. Hepato-Gastroenterology 59(114): 1-22, 2012.

20 Greif F, Ben-Ari Z, Taya R, Pappo O, Kurtzwald E, Cheporko Y, Ravid A and Hochhauser E: Dual effect of erythropoietin on liver protection and regeneration after subtotal hepatectomy in rats. Liver Transplant 16: 631-638, 2010.

21 Sakamoto T, Liu Z, Murase N, Ezure T, Yokomuro S, Poli V and Demetris JA: Mitosis and apoptosis in the liver of interleukin6-deficient mice after partial hepatectomy. Hepatology 29(2): 403-411, 1999.

22 Zimmermann A: Regulation of liver regeneration. Nephrol Dial Transplant 19(4): 6-10, 2004.

23 Blindenbacher A, Wang X, Langer I, Savino R, Terracciano L and Heim MH: Interleukin 6 is important for survival after partial hepatectomy in mice hepatology. Hepatology 38(3): 674682, 2003.

24 Fukuhara Y, Hirasawa A, Li X-K, Kawasaki M, Fujino M, Funeshima N, Katsuma S, Shijima S, Yamada M, Okuyama T, Suzuki $\mathrm{S}$ and Tsujimoto G: Gene expression profile in the regenerating rat liver after partial hepatectomy. J Hepotol 38 : 784-792, 2003.

25 Sudo K, Yamada Y, Saito K, Shimizu S, Ohashi H, Kato T, Moriwaki H, Ito $\mathrm{H}$ and Seishima M: Tnf-a and il-6 signals from the bone marrow derived cells are necessary for normal murine liver regeneration. Biochim Biophys Acta 1782(11): 671-679, 2008. 